\title{
Juhaltswerzetduts.
}

Wortoort . . . . . . . . . . . . . . . III

Degrĭnbung zum Entrourf eines Selebes iber eine auberorbentlide

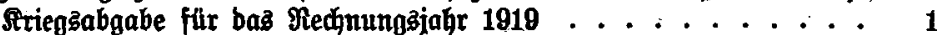

Celeb aber eine auberorbentlime striegsabgabe fur bas

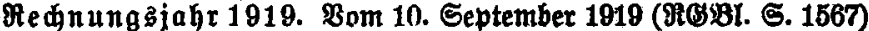

Ulbgabepflidt ber Einzclperionen ............

abgabepflicht ber gicl.l.ldgaften . . . . . . . . . . . 82

Semeinlame Boridriften. . . . . . . . . . . . 182

Sqhüboridriften ................ 169

Degrünoung zum Entwurf eines Seletes iber eine fricgąabgabe vom Bermögengumadjfe. . . . . . . . . . . . . . 172

Befe über eine Ariegabagabe bom Bermögensauwade. Bom

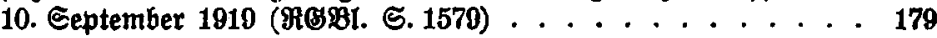

\section{Anhang: Befobesterte.}

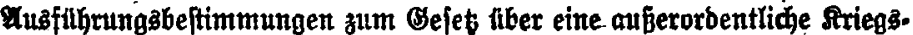

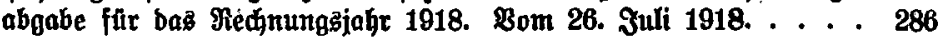

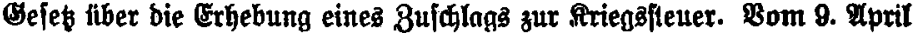

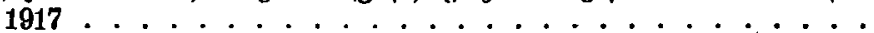

Berorbnung $\mathfrak{a b e r}$ Maßnahmen gegen bie Rapitalabwanbenng in bas

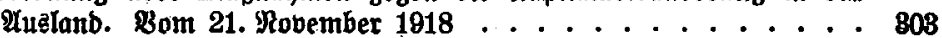

Berorbnung zur Exgänzung ber Berorbnung über Mafnahmen gegen bie fiapitalabtwanbening in bas alualano vom 21. Ravember 1818. Bom 15. Januar 1919 . . . . . . . . . . . . . . . . :

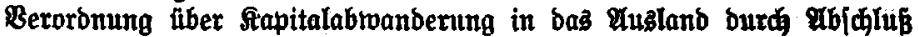
bon Belficherungen: Bom 15. Januar 1919......... 311

Bejeb gegen bie \$apitalfludt. \$om 8. September 1019 . . . . . 813

Beroromung über Maßnahmen gegen bie Stapitalfludt. Som 24. Dttober $1919 \ldots \ldots . . . . . . .315$

Bejeł gegen bie Steuerfluđt. Bom 26. Juli 1918 ......... 320

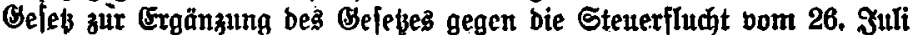
1918. ßom 24. Juni 1919 . . . . . . . . . . . . . . . 327

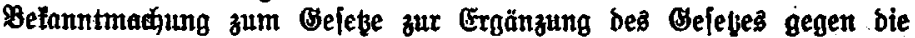

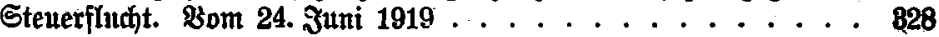

Sadjregifter. . . . . . . . . . . . . . . . . $\$ 80$ 
